DOI 10.18551/rjoas.2021-11.12

\title{
DETERMINATION OF HUMAN DEVELOPMENT INDEX IN SUMATRA
}

\author{
Sumarni ${ }^{1}$, Efiani $^{2}$, Massora Agustina ${ }^{1}$, Yolanda $^{1 *}$, Lecturers \\ ${ }^{1}$ University of Borobudur, Jakarta, Indonesia \\ ${ }^{2}$ STIE Pariwisata International, Indonesia \\ *E-mail: yolanda@borobudur.ac.id
}

\begin{abstract}
This study discusses the Human Development Index (HDI) and the factors that influence it. The Human Development Index (HDI) is a composite indicator to measure the achievement of development in the quality of human life. The measurement indicators are longevity and healthy living, knowledge, and a decent standard of living. While the factors that affect the Human Development Index (HDI are education, poverty, and unemployment. This study uses the Fixed Effect Model (FEM) regression of panel data from 10 provinces on the island of Sumatra in 2006-2019. The results of the study state that simultaneously, education, poverty, and unemployment have a significant and significant effect on the Human Development Index (HDI). Moreover, partially, education has a positive and significant effect on the Human Development Index (HDI), while poverty has a negative and significant effect on the HDI, and so does unemployment. This study implies the importance of the government to pay attention to education, poverty, and unemployment in accelerating human development.
\end{abstract}

\section{KEY WORDS}

Human Development Index (HDI), education, poverty, unemployment.

Countries that were hit by the crisis in 1998, 2008, and 2020 experienced a multidimensional crisis. The multidimensional crisis experienced was a crisis in the financial, economic, and 2020 sectors, including the health crisis. One of the impacts of the crisis caused the growth of the Human Development Index (HDI) in the country to experience a slowdown. In this case, Indonesia is no exception.

The slowdown in HDI growth during the COVID-19 pandemic was caused by growth in life expectancy and education and real spending per capita, which decreased due to the contraction of economic growth. In 2019, Indonesia's HDI value reached 71.8 , which is included in the category of high human development, and this value positions Indonesia at 107 th out of 189 countries and regions. While in 2020, Indonesia's HDI reached 71.94 and grew by 0.14 percent, which was much slower than the previous year's growth of 0.74 percent. follows:

The development of Indonesia's Human Development Index (HDI), 2015-2020, is as

Table 1 - Indonesia Development Index (HDI) 2015-2020

\begin{tabular}{|c|c|c|c|}
\hline No. & Year & HDI & Growth HDI (\%) \\
\hline 1 & 2015 & 69,55 & 0,94 \\
\hline 2 & 2016 & 70,18 & 0,91 \\
\hline 3 & 2017 & 70,81 & 0,90 \\
\hline 4 & 2018 & 71,39 & 0,82 \\
\hline 5 & 2019 & 71,92 & 0,74 \\
\hline 6 & 2020 & 71,94 & 0,03 \\
\hline
\end{tabular}

Source: Central Bureau of Statistics.

Indonesia consists of five major island groups, namely Sumatra, Java, Bali and Nusa Tenggara, Kalimantan, Sulawesi, and Maluku, Papua. HDI growth is slowing in all provinces. The highest HDI was still achieved by the Province of DKI Jakarta (80.77), while the lowest 
achievement was occupied by the Province of Papua (60.44), where 24 provinces experienced an increase in HDI, while ten other provinces experienced a decrease.

For the island of Sumatra, nine out of ten provinces have "high" human development status $(70 \leq \mathrm{HDI}<80)$, and only one province still has "moderate" status $(60 \leq \mathrm{HDI}<70)$, namely Lampung Province. While the average HDI on the island of Sumatra can be seen in Table 2 below:

Table 2 - Indonesia Development Index (HDI) on the island of Sumatra, 2015-2020

\begin{tabular}{|c|c|c|c|}
\hline No. & Year & Average HDI, Sumatera Island & Growth HDI (\%) \\
\hline 1 & 2016 & 69,99 & - \\
\hline 2 & 2017 & 70,57 & 0,83 \\
\hline 3 & 2018 & 71,18 & 0,86 \\
\hline 4 & 2019 & 71,77 & 0,83 \\
\hline 5 & 2020 & 71,78 & 0,01 \\
\hline
\end{tabular}

Source: Central Bureau of Statistics.

Based on the table above, it can be seen that the average Human Development Index on the island of Sumatra rose very little, especially in 2010-2020. The COVID-19 pandemic caused the low growth of the human development index in 2020. The COVID-19 pandemic occurred evenly throughout the world and has caused a multidimensional crisis. Health problems are the beginning of the crisis in Indonesia and continue to the economic and political crisis. As a result of this crisis, Indonesia's human development data and information are expected to assist the government, business, education, and society in formulating better and more sustainable development strategies. Besides, HDI is also an indicator of the success of the economic development of a region.

According to Arisman (2018), Sulistyowati, Sinaga, \& Novindra (2017), and Vikash (2019), an increase in the human development index is an increase in the number of people who can access development in obtaining basic needs (income, health, education) equally. Meanwhile, according to Martinez et al. (2019), an increase in the Human Development Index (HDI) can be through increasing Human Resources (HR) and one of the efforts to overcome the problem of poverty. In addition, according to the Indonesian Central Bureau of Statistics, humans are no longer only inputs from development, but humans have become the ultimate goal of development. Based on this, the problem of human development has become a priority scale in achieving development goals.

Human development is already the main goal in development, and it is necessary to pay attention to the factors that affect human development. The factors that affect human development is implemented in the form of a human development index, have been studied by many researchers. In the last two years, research on the Human Development Index has been researched by Andi Ika Fahrika et al. (2020), Eri Mardison (2020), Elistia and Barlia Annis Syahzuni (2018), Jihad Lukis Pan Answerand Bhimo Rizky Samudro (2021), Nuke et al. ( 2020), Zainal Arifin et al. (2020), Erwan Wahyu Hidayat et al. (2020) and Regina et al. (2020).

Based on the above, the authors want to see the effect of education, inflation, poverty, and unemployment on human development. The problem to be studied is the influence of education, infrastructure, poverty, unemployment on the human development index simultaneously and partially.

\section{LITERATURE REVIEW}

The Human Development Index was first launched in 1990. The United Nations Development Program introduced the calculation of the Human Development Index (HDI) (UNDP) using the components of Life Expectancy at birth (UHH), Literacy Rate (AMH), and GDP per capita using the average method arithmetic mean. In publishing the United Nations Development Program (UNDP) through the Human Development Report in 1996, the components of HDI were productivity, equity, sustainability, and empowerment. In 2010 the 
United Nations Development Program (UNDP) conducted changes in indicators, namely: 1. Aggregation of Literacy Rate (AMH) and the combination of Gross Enrollment Rate (APK) is changed to aggregation of Average Years of Schooling (RLS) and Expected Years of Schooling (HLS); 2. GDP per capita is converted to Gross National Product (GNP) per capita. UNDP periodically makes improvements in this HDI calculation, wherein in 2010 the calculation method changed to the geometric average. In 2014, the base year of GNI per capita to 2011 and calculated the average education index from geometric to arithmetic average.

In Indonesia, HDI was launched for the first time in 1996, with its components being Life Expectancy at Birth (UHH), Literacy Rate (AMH), Average Years of Schooling (RLS), and per capita expenditure using the arithmetic mean method. In 2014 there was a change in the calculation method using the method proposed by UNDP.

Classification of HDI values are:

- $\quad$ HDI "low" group with criteria for HDI < 60;

- HDI group "medium" with criteria $60 \mathrm{HDI}$ value < 70;

- HDI group "high" with criteria $70 \mathrm{HDI}$ value < 80;

- HDI group is "very high" with the criteria of HDI value 80.

If the HDI value is closer to 100 , the quality of human resources in the area will be higher. According to Maulana and Bowo (2013), HDI is used as an indicator of measuring the success of a region's development, and Aji et al. (2014) stated that HDI could describe the overall level of welfare. Meanwhile, Irmayanti (2017) stated that HDI is influenced by the availability of job opportunities determined by economic growth, infrastructure, and government policies. Meanwhile, according to Alhudori (2018), the components of Life Expectancy which measure success in the health sector, Literacy Rate, and Average Years of Schooling which measure success in education and people's purchasing power towards basic needs as seen from the average per capita expenditure are of the Human Development Index.

Based on the National Education System Law No. 20 of 2003, education is about creating a learning atmosphere and learning process to develop self-potential to have religious, spiritual strength, self-control, personality, intelligence, noble character, and skills. Meanwhile, Government Regulation of the Republic of Indonesia Number 47 of 2008 explains Compulsory Education for elementary school-age children aged 7-12 years which aims to provide minimum education for Indonesian citizens to be able to develop their potential so that they can live independently in society and continue their education to a higher level. Thus, education can affect human life, and Widiansyah (2017) states that the real problem of education cannot be separated from economic problems. While Atalay (2015) states that education and lifelong learning are basic conditions for developing human resources, Dewi and Sutrisna (2014) state that education is one of the human development indexes.

To know the quality and level of education can be measured by literacy. Literacy is the ability to read and write. If the ability to read and write Latin letters and other letters from the population of an area is high, it is said that the area already has a good level of education. The literacy rate can calculate this literacy. The formula for the literacy rate is:

$$
\text { Literacy Rate }=\frac{a}{b} \times 100
$$

Where: $a=$ total population aged 15 years and over who can read and write; $b=$ total population aged 15 years and over.

According to Yolanda et al. (2020), the problem of poverty is a significant problem for all countries in the world, and poverty is the inability of the population from an economic point of view to meet basic needs as measured from the expenditure side. According to Rank (2004), this disability is grouped into three main factors: individual, cultural, environmental, structural factors, and poverty. According to Mankiw (2006), concepts and strategies are needed. While law no. 13 of 2011, the poor are people who do not have a source of 
livelihood or have a source of livelihood but cannot meet the basic needs appropriate for their own life and that of their family.

The poor have low purchasing power, which causes the ability to meet a decent standard of living to be low. The low standard of living causes human development to be low. According to research by Nuke Amalia et al. (2020), Regina et al. (2020), Baqtiar \& Murjani (2017), Suwandi (2017), and Farida Rahmawati et al. (2012), poverty has a negative and significant effect on human development index. It states that poverty makes the population unable to purchase basic needs to affect the human development index, and ultimately poverty reduction affects the increase in HDI or vice versa.

Unemployed people do not have a job, are looking for work, and already have a job but have not started working. Meanwhile, according to Sukirno (2008), a situation where someone from the labor force wants to get a job but has not yet got it is unemployed. Meanwhile, Sumarsono (2009) unemployment occurs because of a mismatch between demand and supply in the labor market.

Unemployment occurs due to an imbalance between supply and demand in the labor market. The imbalance between demand and supply of labor is caused by the increase in demand which is relatively lower than the increase in supply. It will result in a new equilibrium level in the low-wage market.

A relatively low wage rate will result in workers having low purchasing power as well. This low purchasing power will affect the level of welfare and will automatically impact human development, and according to Yolanda (2017), the Human Development Index is a benchmark in achieving quality human development.

According to Meydiasari \& Soejoto (2017) and Rita Herawaty Bangun (2021), the unemployment rate has a significant effect on HDI, but Arisman (2018), states that the unemployment rate has no impact on the human development index.

\section{METHODS of RESEARCH}

The analytical method used is quantitatively based on secondary data in a literature review for the relationship between HDI and education, poverty, and unemployment. This research method was carried out in three stages: the first is conducting a literature study with related variables. The second stage is the presentation of the data. The data that has been collected is then processed with e-views and presented in tabular form. The data collected is data on HDI, education, poverty, and unemployment from 10 provinces on the island of Sumatra for the period 2006-2019. At the same time, the third stage is the discussion of research results.

The research method used is 1) Data analysis used multiple linear regression and to find out the contribution (influence) of the independent variable to the dependent variable can be seen from the coefficient of determination or $\mathrm{R}^{2}$. 3) Hypothesis Testing, which consists of a) Individual Parameter Significance Test (t-Test). b) Simultaneous Significance Test (F Test). The data used is panel data, so that the regression models that appear are Common Effect Model / Pooled Least Square (PLS), Fixed Effect Model, and Random Effect Model. From the three-panel data methods above, the best model is selected for panel data analysis. Selection of the best model using the Chow test, Hausman test, and Lagrange multiplier (LM) test. The Chow test is used to choose between the common effect model and the fixed-effect model; the best model decision if the Chi-square Cross-section Probability value is greater than $=0.05$, then the best model is the Common Effect Model if the Chisquare Cross-section Probability value is smaller than $=0.05$ then the best model chosen is the Fixed Effect Model and the test continues on the Hausman test. The Hausman test selects the best model between the fixed effect model and the Random Effect Model. If the Random Cross-section Probability value is greater than $=0.05$, then the model chosen is the Random Effect Model. If the Random Cross-section Probability value is less than $=0.05$, then the best model chosen is the Fixed Effect Model. While the Lagrange multiplier (LM) test is the selection of the best model between the Common Effect Model and the Random Effect Model, if the value ( Prob $>\mathrm{chi}^{2}$ ) $>=0.05$, then the model selected is the Common 
Effect Model and vice versa the value $\left(\right.$ Prob $\left.>\mathrm{chi}^{2}\right)<=0.05$ then the selected model is Random Effect Model.

The data used in this study is secondary data, namely the Human Development Index (HDI) data and the influencing factors for each of the nine provinces on the island of Sumatra. Factors assumed to influence HDI are education (X1), the number of poor people $(X 2)$, and unemployment (X3). Data were obtained from the Central Statistics Agency (BPS) Indonesia.

The model used is linear regression and Pearson Product Moment Correlation coefficient in data analysis with the help of the e-views 8 Statistical Package. The specifications of the regression model are stated as follows:

$$
\operatorname{Ln} \mathrm{HDI}=\mathrm{a}+\beta_{1} \operatorname{Ln} X_{1}+\beta_{2} \operatorname{Ln} X_{2}+\beta_{3} \operatorname{Ln} X_{3+} \text { ei }
$$

Where: Human Development Index = HDI; Education = X1; Poverty = X2; Unemployment = X3; Variable Regression Coefficient: Variable Regression Coefficient $=1 \beta 2 \beta 3$; Intruder Variables $=$ e.

The significance of the model will be calculated by calculating the correlation coefficient $(r)$, and the adjusted coefficient of determination $\left(\overline{R^{2}}\right)$.IThe following hypotheses will be tested:

- Independent variables have no significant effect on the dependent variable;

- The independent variables have a significant effect on the dependent variable.

\section{RESULTS AND DISCUSSION}

Geographically, Sumatra Island is located at $6^{\circ} \mathrm{N}-6^{\circ} \mathrm{S}$ and $95^{\circ} \mathrm{W}-109^{\circ} \mathrm{E}$ with the northern boundary of the Bay of Bengal. Also, to the east of the Malacca Strait, the south of the Sunda Strait, and the west of the Indian Ocean. The island consists of eight mainland provinces (Aceh, North Sumatra, West Sumatra, Riau, North Sumatra, South Sumatra, Bengkulu and Lampung) and two archipelagic provinces (Bangka Belitung Islands and Riau Islands). The total population of the island of Sumatra in 2020 is $53,809,811$ people $(21.68 \%$ of the total population of Indonesia). The first largest population is in the province of North Sumatra and the second in the province of Lampung.

Table 3 - Results of Fixed Effect Model

Dependent Variable: Ln HDI?

Method: Pooled Least Squares

Date: 10/15/21 Time: 10:33

Sample: 20062019

Included observations: 14

Cross-sections included: 10

Total pool (balanced) observations: 140

\begin{tabular}{|c|c|c|c|c|}
\hline Variable & Coefficient & Std. Error & t-Statistic & Prob. \\
\hline $\mathrm{C}$ & -1449001 & 674265.7 & -2.149006 & 0.0335 \\
\hline Ln EDU? & 19289.60 & 6637.999 & 2.905936 & 0.0043 \\
\hline Ln MISKIN? & -218.9105 & 72.21608 & -3.031326 & 0.0030 \\
\hline Ln UNEMP? & -22276.54 & 5126.689 & -4.345210 & 0.0000 \\
\hline R-squared & 0.790828 & \multicolumn{2}{|c|}{ Mean dependent variable } & 142260.4 \\
\hline Adjusted R-squared & 0.771064 & \multicolumn{2}{|c|}{ S.D. dependent variable } & 137648.8 \\
\hline S.E. of regression & 65861.15 & \multicolumn{2}{|c|}{ Akaike info criterion } & 25.11674 \\
\hline Sum squared resid. & $5.51 \mathrm{E}+11$ & \multicolumn{2}{|c|}{ Schwarz criterion } & 25.38990 \\
\hline Log likelihood & -1745.172 & \multicolumn{2}{|c|}{ Hannan-Quinn criteria } & 25.22775 \\
\hline F-statistic & 40.01310 & \multirow{2}{*}{\multicolumn{2}{|c|}{ Durbin-Watson stat }} & 0.518017 \\
\hline Prob (F-statistic) & 0.000000 & & & \\
\hline
\end{tabular}

Source: Processed with E-views 8.

The average GRDP growth rate for the island of Sumatra in 2020 is minus (down $1.19 \%)$; this condition is much better than the islands of Java and Kalimantan, which are minus above $2 \%$. This condition shows that the COVID-19 pandemic has made the economy go down. 
Regression analysis was carried out with the help of software e-views 8, and parameter estimation was presented in 3 models, namely common effect, fixed effect, and random effect. To get the best model of the three models that have been done which is necessary to test the Chow and Hausman test. The first test was carried out between the common and fixed effects, namely the Chow test. The results show that the value of the Probability Crosssection Chi-square is less than 0.05 , which is 0.000 . With this value, the best model chosen is the Fixed Effect Model, and the test is continued on the Hausman Test. The results of the Hausman test show that the value of the Random Cross-section Probability of 0.0000 is less than 0.05 , so the model chosen is the Fixed Effect Model.

From table 3 above, the results of the t-test and discussion of the proposed hypotheses can be obtained as follows:

The effect of education variable on the Human Development Index (HDI), partially education $(\mathrm{X} 1)$ has a significant level of $0.0043<=0.05$ with a t-count of 2.905936. This value indicates that the education variable (X1) has a significant and positive effect on the Human Development Index (HDI). The results of this study explain that increasing education can increase the Human Development Index (HDI).

The poverty variable (X2) on the Human Development Index (HDI, partial poverty has a significant level of $0.0030<=0.05$ with a t-count value of -3.031326 , where the poverty variable (X2) has a significant and negative effect on the Human.

The results of this study explain that a decrease in the number of poor people will increase the Human Development Index (HDI).

The effect of the unemployment variable (X3) on the Human Development Index (HDI), partially unemployment has a significant level of $0.0000<=0.05$ with a t-count value of 4.345210, which means that the unemployment variable (X3) has a significant effect and negative on the Human Development Index (HDI). It shows that increasing unemployment can reduce the Human Development Index (HDI) or vice versa. Unemployment causes a person to have no income, and in the end, it is not easy to access health and the economy. This condition will automatically reduce human development.

The results of the F-statistical test show that the calculated $F$ value is 40.01310 with a probability (sig-F) of 0.0000 . It shows that education, poverty, and unemployment simultaneously significantly affect the Human Development Index (HDI). The coefficient of determination is $79.08 \%$, which means that $79.08 \%$ of changes in the value of the Human Development Index (HDI) are caused by variations in changes in education, poverty, and unemployment variables. Medium 20.92\% influenced by other factors outside of this study. The effect that is produced jointly is high, and partially the relationship of each variable is significant.

Based on table 3 above, the resulting regression equation is:

$$
\operatorname{Ln~HDI~}=-1449001+19289,60 \operatorname{Ln} X 1-218,9105 \operatorname{Ln} X 2-22276,54 \operatorname{LnX} 3+e
$$

Based on the results of multiple linear regression above, it can be interpreted that:

(1) The constant value of the HDI regression equation above is -1449001 . This value indicates that if education (X1), poverty (X2), and unemployment (X3) do not change, then the HDI value will decrease.

(2) The regression coefficient of the education variable $(X 1)$ is 19289.60 . This value indicates that the change from the education variable to the Human Development Index (HDI) is elastic (elasticity $>1$ ). This condition reflects that changes in the education variable have a major impact on the Human Development Index (HDI).

(3) The regression coefficient of poverty (X2) is -218.9105 . This value indicates that an increase in the value of poverty leads to a decrease in the Human Development Index (HDI). It means that an increase in poverty (X2) will have a large decrease in the Human Development Index (HDI), which is reflected in its elasticity greater than one or called elastic.

(4) The coefficient of unemployment variable regression is -22276.54 . This value is also greater than one, meaning that the relationship between unemployment and HDI is elastic. It means that changes from unemployment will have a big impact on HDI. 
From the above, it can be concluded that the relationship between education (X1), poverty (X2), Unemployment (X3), and the Human Development Index (HDI) is elastic.

\section{CONCLUSION}

The Human Resource Development Index (HDI) is one of the important indicators of economic development, and a regression model was built to explain the relationship between education (X1), poverty (X2), Unemployment (X3), and the Human Development Index (HDI). The findings reveal that education (X1), poverty (X2), Unemployment (X3) on the Human Development Index (HDI) are simultaneously positive and significant. While partially the education variable (X1) on the Human Development Index (HDI) is significant and positive, poverty (X2) with the Human Development Index (HDI) is negative and significant, and unemployment with Human Development (HDI) is negative and significant.

With the results of this study, it is hoped that policies on education, poverty, and unemployment will become the main concern in achieving human development. The policy on education related to literacy that the government has carried out is compulsory education for Indonesians aged 7-12 years and is expected to be 18 years old. This age means compulsory education up to high school.

The problems posed by poverty are not only to human development but to development as a whole. For this reason, policies to overcome the problem become the major priority scale. One of the policies to overcome poverty carried out by the government is to provide donations in money (Direct Cash Assistance / BLT). However, it can only solve the problem momentarily. It is hoped that the policy in the form of providing job opportunities will also indirectly reduce unemployment.

\section{REFERENCES}

1. Alhudhori, M. (2017). Pengaruh IPM, PDRB dan jumlah pengangguran terhadap penduduk miskin di Provinsi Jambi. Ekonomis: Journal of Economics and Business, 1(1), 113-124.

2. Aji GB, Suryanto J, Yulianti R, Wirati A, Abdurrahim AY, Miranda TI. (2014), Strategi pengurangan kemiskinan di desa-desa sekitar hutan. Pengembangan model PHBM dan HKm. Laporan Penelitian. Pusat Penelitian Kependudukan. Lembaga IImu Pengetahuan Indonesia, Jakarta

3. Amalia Nuke, Arief Wibowo, Mahmudah (2020), Poverty or People Density Affecting Human Development? Panel Data Regression Study, Indian Journal of Public Health Research \& Development, March 2020, Vol. 11, No. 03, p. 1729-1733.

4. Arisman, A. (2018). Determinant of human development index in ASEAN countries. Signifikan: Jurnal IImu Ekonomi, 7(1), 113-122. https://doi.org/10.15408/sjie.v7i1.6756

5. Arifin Zainal, Indra Maipita, Saidun Hutasuhut (2020), The Effect of Capital Expenditure And Economic Growth On The Human Development Index of The District / City InNorth Sumatera, Advances in Social Sciences Research Journal - Vol.7, No.1, p. 585-594.

6. Atalay, R., 2015. The education and the human capital to get rid of the middle-income trap and to provide the economic development. Procedia-Social and Behavioral Sciences, 174, p. 969-976.

7. Baqtiar, A., \& Murjani, A. (2017), Pengeluaran Pemerintah Daerah Pada Sektor Pendidikan, Kesehatan dan Kemiskinan Terhadap Indeks Pembangunan Manusia (Studi Pada Kabupaten/Kota di Provinsi Kalimantan Selatan). Jurnal Transformasi Administras, 07(9), 1689- 1699.

8. Dewi, N. L. S. and I. K. Sutrisna (2014). "Pengaruh Komponen Indeks Pembangunan Manusia Terhadap Pertumbuhan Ekonomi Provinsi Bali." E-Jurnal Ekonomi Pembangunan, vol 3 no. 3, p. 76-123.

9. Elistia1 and Barlia Annis Syahzuni (2018), The Correlation of The Human Development Index (Hdi) Towards Economic Growth (Gdp Per Capita) In 10 Asean Member Countries, J. of Humanities And Social Studies Volume 02, Number 02, September 2018, P. 40-46. 
10. Eri Mardison (2020), Analysis of Human Development Index in Sumatera Barat Province using Biplot Method, Eko-Regional, Vol 15, No. 1, p. 25-31.

11. Ika Fahrika Andi, Hasni Salam, Muhammad Abdi Buhasyim (2020), Effect of Human Development Index (HDI), Unemployment, and Investment Realization toward Poverty in South Sulawesilndonesia, The International Journal of Sciences World, Vol. 2 No. 02, October 2020, p. 110 116.

12. Lukis Panjawa Jihad and Bhimo Rizky Samudro (2021), The reduction of human development gap in origin and new regency in Eastern Indonesia, Journal of Socioeconomics and Development, 4(1), p. 21-32.

13. Irmayanti. (2017). Pengaruh Indeks Pembangunan Manusia terhadap Pertumbuhan Ekonomi di Kabupaten Polewali Mandar (Skripsi). Jurusan IImu Ekonomi, Fakultas Ekonomi dan Bisnis Islam. Universitas Islam Negeri Alauddin Makassar.

14. Maulana, R. \& Bowo, P. A. (2013). Pengaruh Pertumbuhan Ekonomi, Pendidikan dan Teknologi terhadap IPM Provinsi di Indonesia 2007-2011. Journal of Economics and Policy. 6 (2), p. 163-169.

15. Martínez-Guido, S. I., González-Campos, J. B., \& Ponce-Ortega, J. M. (2019). Strategic planning to improve the Human Development Index in disenfranchised communities through satisfying food, water and energy needs. Food and Bioproducts Processing, 117, 14-29.

16. Mankiw, N. G. (2006). Teori Makro Ekonomi (5th ed.).

17. Melliana, A., \& Zain, I. (2013). Analisis Statistika Faktor Yang Mempengaruhi Indeks Pembangunan Manusia Di Kabupaten/Kota Provinsi Jawa Timur Dengan Menggunakan Regresi Panel. Jurnal Sains Dan Seni POMITS, (2), 237- 242.

18. Rahmawati Farida, Afrilia Nur Aini, Elmira Mufliha Camila (2021), Analysis of The Gender Development Index In East Java Regency/City In 2017-2019, Jurnal REP (Riset Ekonomi Pembangunan) Volume 6 Number 1, p. 61-72.

19. Regina,Bahar Singring, Arifin (2020), Analysis The Effects of Poverty, General Allocation Fund And Economic Growth To Human Development Index (HDI) In Indonesia, Economic Resources Vol. 3 No. 1, p.1- 12.

20. Rita Herawaty Bangun (2021), Disparitas Pembangunan Manusia Di Sumatera Utara, Jurnal Akuntansi Dan Ekonomi, Vol. 6 No. 1, p. 75-84.

21. Sulistyowati, N., Sinaga, B. M., \& Novindra. (2017). Impacts of government and household expenditure on human development index. Journal of Economics and Policy, 10(2), 412-428. https://doi.org/10.15294/jejak.v10i2.11305.

22. Suwandi (2016), The Influence of Economic Growth on Poverty, Investment, and Human Development Index in Fak, Fak District, West Papua Indonesia, IOSR Journal of Economics and Finance (IOSR-JEF), Volume 7, Issue 3. P. 69-72.

23. Vikash, V. (2019). Human development index and gross national happiness indices: a conceptual study. Advances in Management, 12(1), 62-63. Retrieved from https://www.worldresearchersassociations.com/mngmntcurrissue/10.pdf

24. Yakunina R.P, Bychkov G.A. (2015), Correlation Analysis of The Components of The Human Development Index Across Countries, Procedia Economics and Finance 24, p. $766-771$.

25. Wahyu Hidayat Erwan, Rosyadi, Nurul Bariyah (2020), Human Development Index, Unemployment and Poverty Rate in Kalimantan Barat, Prosiding Seminar Akademik Tahunan Ilmu Ekonomi dan Studi Pembangunan, ISBN: 978-602-53460-5-7, Prosiding Seminar Akademik Tahunan IImu Ekonomi dan Studi Pembangunan 2020,ISBN: 978602-53460-5-7, p. 12-23.

26. Widiansyah, A., 2017. The Role of Economics in Education and Education in Economic Development. CakrawalaJ urnal Humaniora, 17(2), p. 207-215.

27. Yolanda (2017), Analysis of Factors Affecting Inflation and its Impact on Human Development Index and Poverty in Indonesia, Volume XX, Issue 4B. p. 38 - 56.

28. Yolanda, Indah Purnama Sari, Srie Nuning Mulatsih and Agustina Massora (2020) J. of Adv. Research in Dynamical \& Control Systems, Vol. 12, No. 7, p. 477- 483. 